
\title{
26 Research Soure \\ Nutritional Status And Associated Factors Among Lactating Women In Eastern, Ethiopia
}

\section{Zerihun Tariku ( $\nabla$ ztariku132@gmail.com )}

Dire Dawa University

\section{Bereket Tefera}

Dire Dawa University

\section{Serawit Samuel}

Dire Dawa University

\section{Tariku Derese}

Dire Dawa University

\section{Melese Markos \\ Dire Dawa University}

\section{Samuel Dessu}

Wolkite University

\section{Research}

Keywords: lactating women, Undernutrition, Dire Dawa, Ethiopia

Posted Date: June 2nd, 2021

DOl: https://doi.org/10.21203/rs.3.rs-536295/v1

License: (c) (i) This work is licensed under a Creative Commons Attribution 4.0 International License. Read Full License 


\section{Abstract}

Background: The nutritional status of lactating women is very important since it also affects the health of their children. However, there was limited information on maternal nutrition status in low-income countries like Ethiopia, especially in the study area.

Methods: Institutional based cross-sectional study was conducted among 401 lactating women in Dire Dawa town health facilities from February 10/02/2019 - March 30/ 03/2019. All variables with a p-value of less than 0.25 were entered into multivariable logistic regression to identify factors associated with undernutrition.

Result: Prevalence of undernutrition was $22 \%$. Women who age $15-25$ years were four times more likely undernourished than older [AOR=4.04(Cl: $(1.74,9.40)]$. Unable to read and write Women were almost five times more likely to be undernourished than formal education [AOR=4.76 Cl: $(2.31,9.81)]$. Women who have family size $>7$ were six times more likely to be undernourished than family size $<3$ [AOR=5.53 $\mathrm{Cl}:($ $1.15,26.53)]$. Women not take additional food during lactating were 4.5 times more likely undernourished than take additional food $[A O R=4.56 \mathrm{Cl}(1.50,13.9)]$. DD score $<5$ were four times more likely to be undernourished than $(>=5)$ DD [AOR= $4 \mathrm{Cl}:(2.02,7.90)]$.

Conclusion: prevalence of undernutrition in the study area was high: Factors associated with undernu+trion were: Age of lactating women, Education status, and Family size, Additional food during lactation and DD score. Thus, multi-sectoral collaboration targeted at improving women's educational status and increasing food during lactation need to be emphasized.

\section{Background}

Undernutrition and its associated disease conditions can be caused by eating too little, or eating an unbalanced diet that lacks necessary nutrients. Undernutrition, defined as failure to consume adequate energy, protein, and micronutrients to meet basic requirements for body maintenance, growth, and development [1]. Malnutrition is one of the most devastating problems worldwide and is inextricably linked with poverty [2].

Women are more likely to suffer from nutritional deficiency than men including their reproductive biology, low social status, poverty and lack of education. Physiologically, women are more likely to be malnourished, especially if they are menstruating, pregnant, or lactating [3]. In addition, socio-cultural traditions and disparities in household work patterns can also increase women's chance of being malnourished [4].

Nutrition throughout life has a major effect on health. This is true for lactating women as adequate maternal nutrition is one of the best ways to ensure maternal and fetal wellbeing in developed and developing countries [2].Diet quality in the first 1000 days of life, is fundamental for physical and mental development as well as maintaining good health in later life. Large segment of worlds' population being 
undernourished or have low mineral and vitamin status due to lack of availability or inability to access to food of quality of diet or malabsorption. So providing a nourishing diet for pregnant and lactating mother results in significantly better infant health outcomes [5].

In sub-Saharan Africa (SSA), south-central and south-eastern Asia, more than $20 \%$ of women were underweight. The prevalence of women having body mass index less than $18.5 \mathrm{~kg} / \mathrm{m}^{2}$ in Bangladesh, Eritrea and India goes up to $40 \%$ [5]. However Survey evidence in Indonesia, Tibetan and Myanmar showed that the prevalence of undernutrition among lactating women was range from $9-12 \%[6,7,8]$.

In Ethiopia based on 2016 EDHS report 22\% women are underweight or thin, and $8 \%$ are overweight or obese(14). Some studies showed that in Ethiopia the prevalence of underweight (BMI $<18.5 \mathrm{~kg} / \mathrm{m} 2)$ among lactating women ranges from $20-40.6 \%$ [9,10,11,12].

Undernutrition among lactating women contributes to risk of neonatal deaths and stunting by 2 years of age. Suboptimum breastfeeding results in an increased risk for mortality in the first 2 years of life and it cause 800,000 child deaths annually $[2,3]$. Suboptimum breastfeeding, stunting, wasting, and deficiencies of vitamin A and zinc, cause $45 \%$ of child deaths, resulting in 3.1 million deaths annually [3].

Information on the nutritional status of the lactating mother and associated factors is needed for prioritizing, designing and initiating intervention programs aimed at improving maternal nutrition. However, there is limited information on nutritional status of lactating women and associated factor. Therefore, this study is aimed to assess the prevalence of undernutrition and associated factors among lactating women in Dire Dawa Health facilities, Eastern, Ethiopia.

\section{Methods}

\section{Study Area and Period}

The study was conducted in Dire Dawa city administration which is located in the Eastern part of the Ethiopia. According to the Ethiopian central statistics authority's 2008 report, Dire Dawa administrative region has total population of 453,000 of whom almost one to one male to female ratio. It is situated $515 \mathrm{Kms}$ from Addis Ababa. Dire Dawa city administration is one of the two City Administration and majority of its population lives in urban area with 233,224 or around $68.22 \%$ of the population are urban inhabitants. The public health organizations which are involved in health care delivery include 1 public referral hospital, 1 public district hospital and 8 public health centers. All health institutions provide maternal health service in addition to other service. The study was conducted from February 10/02/2019 - March 30/ 03/2019.

\section{Study Design}

Institutional based cross sectional study design was used.

\section{Population}




\section{Source population}

All lactating mothers living in Dire Dawa City who were visiting Dire Dawa Health facilities for postnatal care and EPI program was considered as the source of population.

\section{Study population}

Selected lactating mothers who visiting Dire Dawa Hospitals and Health Centers for postnatal care and EPI program during data collection period were considered as study population.

\section{Inclusion and exclusion criteria}

\section{Inclusion Criteria}

Those lactating mothers living in Dire Dawa City and who was visiting at Dire dawa Hospitals and Health centers for post-natal care and EPI program during the study period.

\section{Exclusion Criteria}

Lactating women who were critical ill, pregnant and physical deformity will be excluded from the study to improve quality of anthropometric measurements.

\section{Sample size determination for first objective}

The required sample size was determined using formula for single population proportion $(\mathrm{n}=$ $\left.\left.(\mathrm{Z} / 2)^{2} \mathrm{pq} / \mathrm{d}^{2}\right)\right)$ with the following assumptions:

- Confidence level at $95 \%(Z)=1.96$

- Margin of error (d) $=0.04$ or $4 \%$

- $10 \%$ for non-response rate

- Prevalence of undernutrition among lactating women in Nekemt referral hospital and health centers to be $20 \%(12)$.

Thus, $n=\frac{Z^{2} p q}{d^{2}}$

$n=\frac{z^{2} p q}{d^{2}}=\frac{(1.96)^{2}(0.20)(0.8)}{(0.04)^{2}} \quad \mathrm{n}=$ the required sample size

$\mathrm{n}=\mathbf{3 8 4}$

By considering of $10 \%$ non-response rate, the total sample size for the first specific objective was (384+ $38.4)=422$.

\section{Sampling Procedure}


First select one hospital and three health center by using simple random sampling method from all health facility found in Dire Dawa city. The calculated sample size was proportionally allocated to the hospital and health centers based on their population size according to the average number of clients registered prior to the study period in the respective institutions. Then the number of all lactating women were taking from each selected health facilities by using systematic sampling method.

\section{Data collectors and data collection procedures}

The data will be collected by 8 nurses' work in the post-natal and EPI service and the data was collect at exit. Data collectors were trained for two days by principal investigator. Two BSC holders in Nursing or health officer will be recruited and trained for supervising data collectors. Training was given about methods of anthropometric measurement, interviewing technique and filling questionnaires.

To measure weight of mother requested to remove shoe, wear light close and other supportive materials and data collectors were weigh the study participant on calibrated portable digital scale and value will be recorded to the nearest 100 gram or $0.1 \mathrm{~kg}$.

To measure height the study participant was requested to stand erect with their shoulder level, hands was at the side, head, scapulae, buttock and heel were in contact with vertical measuring board with sliding head bar and height value will be recorded to the nearest $0.1 \mathrm{~cm}$. (WHO 2012)

\section{Data quality control}

To assure the quality of the data, structured and pretested questionnaire was used. Pretest of the questionnaire was employed prior to actual data collection period among $5 \%$ of the study sample on one health center not included in this study. The final version of the questionnaire which was prepared in English translated into the local language of the respondents (Amharic language) and again translated back to English. The data collectors and supervisors were given two day intensive training by principal investigator $(\mathrm{PI})$ on the instruments, method of data collection, how to take anthropometric measurements and ethical issues.

Relative Technical error Measurement (\%TEM) was done to minimize the random anthropometric measurement errors and relative TEMs for intra and inter examiners for weight and height was acceptable if relative technical error Measurement less than $1.5 \%$ and $2 \%$ respectively (Perini. et al., 2005). Functionality of digital weight scales will be checked using known weight every morning before data collection begin and before every weight measurement the data collectors were assure the scale reading exactly at zero (31).

Intensive supervision were done by principal investigator and supervisor and they were check the collected data for completeness, accuracy, and consistency throughout the data collection period. The overall supervision was done by the principal investigator. Data double entry was used to make comparisons of two data cells and resolve if there is some difference.

\section{Data processing and analysis}


Data was coded and entered on to Epi-data version 3.0 and exported to SPSS Version 22 for analysis. Missing values checked by conducting simple frequency analysis. Exploratory data analysis was done to check missing values, potential outliers and the normality distribution for those continuous variables.

Multi-Collinearity effect was checked and variables with SE $>2$ was removed from analysis and those variables have no collinear effect was included in binary logistic regression model to see the possible relationships with the outcome variables. Covariates with a p-value less than 0.25 in the bivariable logistic regression analysis was candidate for a multivariable logistic regression analysis to control potential confounders and to identify associated factors of undernutrition. The fitness of the model was tested by Hosmer- Lemeshow goodness of fit test ( $p$-value $=0.83$ ). Odd Ratios along with $95 \%$ Confidence interval was estimated measure the strength of the association. Level of statistical significance was declared at $\mathrm{p}$-value less 0.05 . Results were presented using frequencies, summary measures, tables, and figures.

\section{Results}

\section{Socio-demographic characteristics of study participants}

A total of 401 lactating women aged $15-49$ were interviewed, with a response rate of $95 \%$. Almost half, $176(43.9 \%)$ of the respondents were in the age group of $26-35$ years. The mean ( \pm SD) age of respondents were $28.7( \pm 6.2)$ years. Majority, $368(91.8 \%)$ of study participants were married. one hundred eighty-nine (47.1\%) lactating women were orthodox religion followers. Regarding to education status, 59 (14.7\%) women and $48(12 \%)$ husband, were not able to read and write. From the total study participant, $162(40.4 \%)$ lactating women were housewife. Majority, $323(80.5 \%)$ of the study participants lived in male-headed households. More than one fourth, 119 (29.6\%) study participants have family size seven and more than seven (Table 1). 
Table 1

Socio-demographic characteristics of lactating women whose age is 15-49 years in in Dire Dawa town, Eastern Ethiopia, 2019/20 ( $\mathrm{n}=401)$

\begin{tabular}{|c|c|c|c|}
\hline Variables & Category & Frequency & Percent \\
\hline \multirow[t]{3}{*}{ Age of lactating women } & $15-25$ year & 149 & 37.2 \\
\hline & $26-35$ year & 176 & 43.9 \\
\hline & $36-49$ year & 75 & 18.7 \\
\hline \multirow[t]{2}{*}{ Current marital status of women } & Married & 368 & 91.8 \\
\hline & Other* & 33 & 8.2 \\
\hline \multirow[t]{3}{*}{ Religion of women } & Orthodox & 189 & 47.1 \\
\hline & Muslim & 134 & 33.4 \\
\hline & Protestant & 78 & 19.5 \\
\hline \multirow[t]{5}{*}{ Education of women } & Unable to read and right & 59 & 14.7 \\
\hline & Able to read and write & 103 & 25.7 \\
\hline & Only primary & 91 & 22.7 \\
\hline & Secondary & 107 & 26.7 \\
\hline & College diploma and above & 41 & 10.2 \\
\hline \multirow[t]{5}{*}{ Education of husband } & Unable to read and right & 48 & 12.0 \\
\hline & Able to read and write & 64 & 16.0 \\
\hline & Only primary & 85 & 21.2 \\
\hline & Secondary & 147 & 36.6 \\
\hline & College diploma and above & 57 & 14.2 \\
\hline \multirow[t]{4}{*}{ Occupation of women } & Housewife & 162 & 40.4 \\
\hline & Daily labor & 51 & 12.7 \\
\hline & Private employee & 67 & 16.7 \\
\hline & Government employee & 121 & 30.2 \\
\hline \multirow[t]{3}{*}{ Occupation of husband } & Daily labor & 146 & 36.4 \\
\hline & Private employee & 78 & 19.5 \\
\hline & Government employee & 177 & 44.1 \\
\hline Head of the house hold & Male & 323 & 80.5 \\
\hline
\end{tabular}




\begin{tabular}{|c|c|c|c|}
\hline Variables & Category & Frequency & Percent \\
\hline & Female & 78 & 19.5 \\
\hline \multirow[t]{3}{*}{ Family size } & $1-3$ & 76 & 19.0 \\
\hline & $4-6$ & 206 & 51.4 \\
\hline & $>=7$ & 119 & 29.6 \\
\hline
\end{tabular}

With regard to household food security, $107(26.7 \%) 95 \% \mathrm{Cl}(22.4,30.9)$ of the households were food insecure while the remaining $294(73.3 \%) 95 \% \mathrm{Cl}(69.1,77.6)$ of the households were food secured during study period (figure-1).

\section{Maternal Health Care and Feeding Practices}

Majority, 245 (61.1\%), lactating women received antenatal care (ANC) at least once during their last pregnancy. But 39 (9.7\%) lactating women were not taken ANC follow up during their pregnancy and also only $117(29.2 \%)$ of study subject had ANC visits of greater than or equal to 4 times (which is recommended). 176 (43.9\%) of the study participants had 3-6 previous pregnancies. Only one third (28.4 $\%)$ of the respondent had birth interval $>2$ years for their last delivery. From the total study participants, $96(23.9 \%)$ got their first pregnancy in less than 18 years. More than three fourth (78.8\%) study subject have got nutrition education. Majority, 360(89.8\%) of the study participant did not avoid any food because of cultural/traditional reasons, whereas, only 83 (20.7\%) of them were eating additional foods during their lactation period. The mean \pm SD of women dietary diversity score of lactating mothers in the study area was $5 \pm 1.5$, majority of them, $258(64.3 \%)$ had DDS of $>=5$ and $143(35.7 \%)$ lactating women had < 5 DDS. From the total participant, $102(25.4 \%)$ of respondents had experienced illness in the past two weeks preceding the study time. Concerning latrine availability, only $33(8.2 \%)$ of households included in this study had no their own latrine (Table - 2). 
Table 2

Maternal health care and feeding Practices of study participant in Dire Dawa town, Eastern Ethiopia, 2019/20 $(n=401)$

\begin{tabular}{|c|c|c|c|}
\hline Variables & Category & Frequency & Percent \\
\hline \multirow[t]{3}{*}{ Breastfeed child age } & 6-11 month & 170 & 42.4 \\
\hline & $12-18$ month & 158 & 39.4 \\
\hline & 19-24 month & 73 & 18.2 \\
\hline \multirow[t]{3}{*}{ Number of ANC visits } & No visit & 39 & 9.7 \\
\hline & $<4$ visit & 245 & 61.1 \\
\hline & $>=4$ visit & 117 & 29.2 \\
\hline \multirow[t]{4}{*}{ Number of pregnancy } & $\leq 2$ Child & 210 & 52.4 \\
\hline & 3-4 Child & 124 & 30.9 \\
\hline & 5-6 Child & 52 & 13.0 \\
\hline & $>6$ Child & 15 & 3.7 \\
\hline \multirow[t]{2}{*}{ Age at first pregnancy } & $<18$ years & 96 & 23.9 \\
\hline & $>=18$ years & 305 & 76.1 \\
\hline \multirow[t]{3}{*}{ Birth interval } & First birth & 85 & 21.2 \\
\hline & $1-2$ year & 202 & 50.4 \\
\hline & $>2$ year & 114 & 28.4 \\
\hline \multirow[t]{2}{*}{ Place of delivery } & Health facility & 333 & 83.0 \\
\hline & Home & 68 & 17.0 \\
\hline \multirow[t]{2}{*}{ Nutritional education } & Yes & 316 & 78.8 \\
\hline & No & 85 & 21.2 \\
\hline \multirow[t]{2}{*}{ Number of feeding } & $<3$ feed & 107 & 26.7 \\
\hline & $>=3$ feed & 294 & 73.3 \\
\hline \multirow[t]{2}{*}{ Avoiding food during lactation } & Yes & 41 & 10.2 \\
\hline & No & 360 & 89.8 \\
\hline \multirow[t]{2}{*}{ Additionally food consumption } & Yes & 83 & 20.7 \\
\hline & No & 318 & 79.3 \\
\hline Women dietary diversity & $<5 \mathrm{DD}$ & 143 & 35.7 \\
\hline
\end{tabular}




\begin{tabular}{|lllll|}
\hline Variables & Category & Frequency & Percent \\
\hline History of illness & >=5 DD & 258 & 64.3 \\
& Yes & 299 & 74.6 \\
\cline { 2 - 4 } & No & 102 & 25.4 \\
& Yes & 33 & 8.2 \\
\hline
\end{tabular}

\section{Nutritional Status of Lactating Women}

The nutritional status of lactating women was measured by Body Mass Index (BMI). Accordingly, the mean (+ SD) BMl was $21(+2.4) \mathrm{Kg} / \mathrm{m} 2$. From the total study participants, $88(22 \%) ; 95 \% \mathrm{Cl}(18,25.9)$ had $\mathrm{BMI}$ of $<18.5 \mathrm{Kg} / \mathrm{m} 2$ and $288(71.8 \%) ; 95 \% \mathrm{Cl}(67.6,76.1)$ were in normal range (figure-2).

\section{Factors associated with undernutrition among lactating women}

To determine the association between undernutrition and explanatory variables, bivariate analysis was performed using logistic regression. The result indicates that there is association between nutritional status of lactating women and some of the explanatory variables under the study such as age of lactating women, educational status of women, Age at first pregnancy, family size, frequency of ANC visit, birth interval for the index child, additional food during lactation, Number of feeding, women dietary diversity and levels of household food insecurity.

In multivariable logistic regression analysis, the covariates: age of lactating women, educational status of women, family size, additional food during lactation and women dietary diversity score were statistically significant at $5 \%$ level of significance and were found to be the predictors of undernutrition among lactating women in the study. Those women who age are 15-25 years four times more likely undernourished than those women age 36 to 49 age during lactating [AOR $=4.04(\mathrm{Cl}:(1.74$, 9.40)].Lactating women unable to read and write were almost five times more likely to be undernourished than women who had formal education $[A O R=4.76 \mathrm{Cl}:(2.31,9.81)]$.Lactating women who have family size $>7$ were six times more likely to be undernourished than women who have family size less than 3 $[A O R=5.53 \mathrm{Cl}:(1.15,26.53)]$.those women not take additional food during lactating were 4.5 times more likely undernourished than women take additional food during lactating. [AOR $=4.56 \mathrm{Cl}(1.50,13.9)]$ Regarding women dietary diversity score, those with dietary diversity score below the mean $(<5)$ were four times more likely to be undernourished than women with score a greater than or equal the mean ( $>=$ 5) $[\mathrm{AOR}=4 \mathrm{Cl}:(2.02,7.90)]($ Table-3) . 
Table 3

Factors associated with undernutrition among lactating women in Dire Dawa town, Eastern Ethiopia, $2019 / 2020(n=401)$

\begin{tabular}{|c|c|c|c|c|c|}
\hline \multirow[t]{3}{*}{ Covariant } & \multirow[t]{3}{*}{ Category } & \multicolumn{2}{|l|}{ BMI } & \multirow{3}{*}{$\begin{array}{l}\text { COR (95\% } \\
\text { Cl) }\end{array}$} & \multirow{3}{*}{$\begin{array}{l}\text { AOR } \\
(95 \% \mathrm{Cl})\end{array}$} \\
\hline & & \multirow{2}{*}{$\begin{array}{l}<18.5 \text { kg/m2 } \\
\text { Undernutrition }\end{array}$} & $\begin{array}{l}>=18.5 \\
\mathrm{~kg} / \mathrm{m} 2\end{array}$ & & \\
\hline & & & & & \\
\hline \multirow[t]{3}{*}{$\begin{array}{l}\text { Age of lactating } \\
\text { women }\end{array}$} & $15-25$ year & 55 (36.9\%) & $\begin{array}{l}94 \\
(63.1 \%)\end{array}$ & $\begin{array}{l}2.59(1.33 \\
5.05)\end{array}$ & $\begin{array}{l}4.04 \\
(1.74 \\
9.40)^{\star \star}\end{array}$ \\
\hline & $26-35$ year & 19 (10.8\%) & $\begin{array}{l}157 \\
(89.2 \%)\end{array}$ & $\begin{array}{l}0.54 \\
(0.25,1.13)\end{array}$ & $\begin{array}{l}0.71 \\
(0.29 \\
1.61)\end{array}$ \\
\hline & $36-49$ year & $14(18.4 \%)$ & $\begin{array}{l}62 \\
(81.6 \%)\end{array}$ & 1 & 1 \\
\hline \multirow[t]{3}{*}{$\begin{array}{l}\text { Education } \\
\text { status of women }\end{array}$} & $\begin{array}{l}\text { Unable to read } \\
\text { and write }\end{array}$ & 28 (47.5\%) & $\begin{array}{l}31 \\
(52.5 \%)\end{array}$ & $\begin{array}{l}5.26(2.82, \\
9.82)\end{array}$ & $\begin{array}{l}4.76 \\
(2.31 \\
9.81)^{\star \star \star}\end{array}$ \\
\hline & $\begin{array}{l}\text { Able to read and } \\
\text { write }\end{array}$ & $25(24.3 \%)$ & $\begin{array}{l}78 \\
(75.7 \%)\end{array}$ & $\begin{array}{l}1.86(1.05, \\
3.32)\end{array}$ & $\begin{array}{l}1.77 \\
(0.88 \\
3.53)\end{array}$ \\
\hline & $\begin{array}{l}\text { Have formal } \\
\text { education }\end{array}$ & 35 (14.6\%) & $\begin{array}{l}204 \\
(85.4 \%)\end{array}$ & 1 & 1 \\
\hline \multirow[t]{2}{*}{$\begin{array}{l}\text { Age at first } \\
\text { pregnancy }\end{array}$} & $<18$ years & $27(28.1 \%)$ & $\begin{array}{l}69 \\
(71.9 \%)\end{array}$ & $\begin{array}{l}1.56(1.03, \\
2.65)\end{array}$ & $\begin{array}{l}0.92 \\
(0.48 \\
1.75)\end{array}$ \\
\hline & $>=18$ years & $61(20 \%)$ & $244(80 \%)$ & 1 & 1 \\
\hline \multirow[t]{3}{*}{ Family size } & $1-3$ & $12(15.8 \%)$ & $\begin{array}{l}64 \\
(84.2 \%)\end{array}$ & 1 & 1 \\
\hline & $4-6$ & $33(16.1 \%)$ & $\begin{array}{l}173 \\
(83.9 \%)\end{array}$ & $\begin{array}{l}1.02(0.49 \\
2.09)\end{array}$ & $\begin{array}{l}3.56(0.78 \\
16.24)\end{array}$ \\
\hline & $>=7$ & $43(36.2 \%)$ & $\begin{array}{l}76 \\
(63.8 \%)\end{array}$ & $\begin{array}{l}3.02(1.47, \\
6.21)\end{array}$ & $\begin{array}{l}5.53 \\
(1.15 \\
26.53) \star \star \star\end{array}$ \\
\hline \multirow[t]{2}{*}{$\begin{array}{l}\text { Number of } \\
\text { ANC visit }\end{array}$} & $<4$ visit & $70(24.6 \%)$ & $\begin{array}{l}214 \\
(75.4 \%)\end{array}$ & $\begin{array}{l}1.79(1.2 \\
3.18)\end{array}$ & $\begin{array}{l}1.76 \\
(0.86 \\
3.59)\end{array}$ \\
\hline & $>=4$ visit & $18(15.4 \%)$ & $\begin{array}{l}99 \\
(84.6 \%)\end{array}$ & 1 & 1 \\
\hline
\end{tabular}




\begin{tabular}{|c|c|c|c|c|c|}
\hline \multirow[t]{3}{*}{ Covariant } & \multirow[t]{3}{*}{ Category } & \multicolumn{2}{|l|}{ BMI } & \multirow{3}{*}{$\begin{array}{l}\text { COR }(95 \% \\
\text { Cl) }\end{array}$} & \multirow{3}{*}{$\begin{array}{l}\text { AOR } \\
(95 \% \mathrm{Cl})\end{array}$} \\
\hline & & \multirow{2}{*}{$\begin{array}{l}<18.5 \text { kg/m2 } \\
\text { Undernutrition }\end{array}$} & $\begin{array}{l}>=18.5 \\
\mathrm{~kg} / \mathrm{m} 2\end{array}$ & & \\
\hline & & & Normal & & \\
\hline \multirow[t]{3}{*}{ Birth interval } & first birth & $18(21.2 \%)$ & $\begin{array}{l}67 \\
(78.8 \%)\end{array}$ & $\begin{array}{l}1.34(0.65 \\
2.75)\end{array}$ & $\begin{array}{l}2.73 \\
(0.67 \\
11.22)\end{array}$ \\
\hline & $1-2$ year & $51(25.2 \%)$ & $\begin{array}{l}151 \\
(74.8 \%)\end{array}$ & $\begin{array}{l}1.68(0.94 \\
3.03)\end{array}$ & $\begin{array}{l}1.24 \\
(0.60 \\
2.50)\end{array}$ \\
\hline & $>2$ year & 19 (16.7\%) & $\begin{array}{l}95 \\
(83.7 \%)\end{array}$ & 1 & 1 \\
\hline \multirow[t]{2}{*}{$\begin{array}{l}\text { additional food during } \\
\text { lactation }\end{array}$} & No & 83 (26.1\%) & $\begin{array}{l}235 \\
(73.9 \%)\end{array}$ & $\begin{array}{l}5.51(2.15, \\
14.1)\end{array}$ & $\begin{array}{l}4.56 \\
(1.50 \\
13.9)^{\star \star \star}\end{array}$ \\
\hline & Yes & $5(6.1 \%)$ & $\begin{array}{l}78 \\
(93.9 \%)\end{array}$ & 1 & 1 \\
\hline \multirow[t]{2}{*}{$\begin{array}{l}\text { Number } \\
\text { of feeding }\end{array}$} & $<3$ feed & 37 (34.6\%) & $\begin{array}{l}70 \\
(65.4 \%)\end{array}$ & $\begin{array}{l}2.52(1.53, \\
4.15)\end{array}$ & $\begin{array}{l}0.67 \\
(0.32 \\
1.64)\end{array}$ \\
\hline & $>=3$ feed & $51(17.3 \%)$ & $\begin{array}{l}243 \\
(82.7 \%)\end{array}$ & 1 & 1 \\
\hline \multirow{2}{*}{$\begin{array}{l}\text { Women dietary } \\
\text { Diversity score }\end{array}$} & $<5$ & $58(40.5 \%)$ & $\begin{array}{l}85 \\
(59.5 \%)\end{array}$ & $\begin{array}{l}5.19(3.12, \\
8.60)\end{array}$ & $\begin{array}{l}4(2.02 \\
, 7.90)^{\star \star}\end{array}$ \\
\hline & $>=5$ & $30(11.6 \%)$ & $\begin{array}{l}228 \\
(88.4 \%)\end{array}$ & 1 & 1 \\
\hline \multirow{2}{*}{$\begin{array}{l}\text { Household } \\
\text { food security }\end{array}$} & Food in secure & $39(41.6 \%)$ & $68(58.4 \%)$ & $\begin{array}{l}2.86(1.74 \\
4.72)\end{array}$ & $\begin{array}{l}1.1(0.53, \\
2.11)\end{array}$ \\
\hline & Food secure & 49 (16.9\%) & $\begin{array}{l}245 \\
(83.1 \%)\end{array}$ & 1 & 1 \\
\hline
\end{tabular}

\section{Discussion}

The prevalence of undernutrition was $22 \%$. Age of lactating women, Education status of lactating women (those unable to read and write), Family size, additional food during lactation and women dietary diversity score were significantly associated with undernutrition.

The prevalence of undernutrition (BMl $<18.5 \mathrm{~kg} / \mathrm{m} 2)$ among lactating women in this study was $22 \%$. This prevalence was much closer to the study documented in Ambo district 21.5\% [9] and Nekemte 20.5\% 
[12]. It also similar to studies Adama 19.5\% [10], Tigray, $24.6 \%$ (24) and also in Amhara region of Wombera district $25.6 \%$ [22]. When this figure is compared with the result of Jimma $40.6 \%$ [11] it is much lower. This discrepancy could probably be attributed to the interventions on maternal health, nutrition and other women empowering programs by the government as well as other non-governmental organizations in the study area and time difference in which the current study was conducted recently after several community-based interventions were undertaken and also due to sample size difference between the studies.

On the contrary, the prevalence is much higher than studies in Indonesia 9\%, (Madanijah.et al., 2016) Tibet 10.3\% [6], Myanmar 11.9\% [8] and Nigeria 5\% [21]. The difference in the prevalence might be due to socio-demographic factors like education status of women and economic differences between the studies areas.

The present study has affirmed that age of lactating women was significantly associated with their nutritional status. Mothers within the age group of 15-25 had four times more likely to be undernourished when compared with those mothers in the age group of 36-49. This is in line with a result from study done in Ambo district indicate that lactating women in age group of 17-25 more exposed to undernutrition than older women [9]. Similarly in Bangladesh and Nepal, younger women in the age group 15-24 were more likely to be undernourished than older women [17, 19]. This is because of younger age lactating women have immature anatomical structure and physiological conditions.

Educational status of lactating women was a factor that predicted their nutritional status in this study. Lactating women who were unable to read and write were five times more likely to be undernourished than those mothers who had formal education. Similar studies from India (35) and also in Ethiopia Ambo district [9] also reported that undernourished women were more common among those with no formal education. This might be related with an increased awareness of self-care, health service utilization and recognizing the importance of increasing meal frequency during lactation among educated women.

In this study, statistically significant association was found between the covariate family size index and nutritional status of lactating women. Women from > 7 family size were 5.53 times more likely to be undernourished than women in the 1-3 family size. This had been also supported by the study from Wombera woreda, Northwest Ethiopia and Nekemte 25.6\% [12, 22]. This association could be due to the fact that women from family size higher were in difficulties of meeting their dietary requirement, engaged in energetic works like daily laborer and have minimal health care practice and also food security issue in women with higher family size and related underweight and nutritional depletion of the mother due to frequent pregnancies.

Additional food during lactation was another factor associated with undernutrition. Accordingly, women who not got additional food during lactation were 4.56 times more likely to be undernourished compared to those who's got additional food during lactation. This had been also supported by a study done in Tigray [23]. This could be because during lactation more energy were required than from normal time 
even more than from pregnancy time, so if the lactating women did not get adequate food during lactation were more exposed to undernutrition.

Dietary diversity score of studied women was also another factor that affects their nutritional status in this study. Those women whose dietary diversity score below the mean $(<5)$ were four times more likely to be undernourished than women with the score a greater than or equal the mean $(>=5)$, implying that eating diverse food groups as a protective to undernutrition. This finding agrees with a study done in Dedo and Seqa-Chekorsa districts, Jimma Zone [11]. This might be because women with low dietary diversity may not get enough balanced diet which is essential for the human body to be immune and perform metabolic activities and also diversified food reflects dietary quality, improves daily nutrient and energy intake. Lactating women who do not get enough energy and nutrients in their diets risk maternal depletion and exacerbates women undernutrition

The current study has the following limitations. An anthropometric measurement error was one of the limitations of this study: To minimize this; data collectors were well trained, standardization of anthropometric measures was done and the instrument was calibrated. Since some of the questions are asking the event that occurs 4 weeks back, there is a possibility that some of the responses might suffer from recall bias and this may affect prevalence estimates. This was minimized by probing the respondents about the event. The strength of this study, it has $96.5 \%$ response rate.

\section{Conclusion}

The result of this study indicated that prevalence of undernutrition $(\mathrm{BMI}<18.5 \mathrm{Kg} / \mathrm{m} 2)$ among lactating women in the study area was high. The predictors of undernutrition among lactating women in the study area were: Education status of lactating women (those unable to read and write), Age of lactating women, Family size, additional food during lactation and women dietary diversity score.

\section{Abbreviations}

AOR Adjusted Odds Ratio

ANC Ante Natal Care

BMI Body Mass Index

CED Chronic Energy Deficiency

CSA Central Statistical Agency

DDS Dietary Diversity Score

EDHS Ethiopian Demographic and Health Survey 
FAO Food and Agriculture Organization

FMoH Federal Minster of Health

HFIAS Household Food Insecurity Access Scale

TEM Technical Error Measurement

NGOs Non-Governmental Organizations

NHANE National Health and Nutrition Examination Survey

UNICEF United Nation Children's Fund

WHO World Health Organization

\section{Declarations}

\section{Ethical Approval and consent to participate}

Before starting of the data collection process, Dire Dawa University School of medicine and college of health sciences Institutional Health Research Ethics Review Committee (IHRERC) was secured by ethical clearance and Dire Dawa University was write Official letter to hospital and health centers with reference number DDU/IHRERC/0867/19. Informed voluntary written and signed consent was obtained from each participant after explaining the purpose and benefits of the study. The data collector were trained to respect the culture of the people in these communities throughout the data collection process. Confidentiality of the study participants' information also ensure.

\section{Consent for publication}

- Not applicable

\section{Availability of data and material}

- "Availability of Data and Materials"

\section{Competing interests}

- The authors declare that they have no competing interests.

\section{Funding}

- All sources of funding for the research was Dire Dawa University.

\section{Authors' contributions}


Bereket Tefera conception and design, acquisition of data, drafting the article and final approval of the version to be published

Serawit Samuel analysis and interpretation of data revising it critically for important intellectual content; and final approval of the version to be published.

Tariku Derese conception and design, acquisition of data, drafting the article and final approval of the version to be published

Melese Markos analysis and interpretation of data revising it critically for important intellectual content; and final approval of the version to be published.

Samuel Dessu conception and design, acquisition of data, drafting the article and final approval of the version to be publishe

\section{Acknowledgements}

First of all, I would like to thanks Dire Dawa University for giving me opportunity to develop this research. I extend my appreciation for staffs of Sabian hospitals, and Gende kore, Goro and Legehare Health centers providing important information and for their unlimited co-operation and also I thank the data collectors, supervisors, study participants, and questionnaire translators; without whom the research would not be done. At the last my appreciation goes to research square for pre-print online my research work.

\section{What is already know on this topic}

- High prevalence of undernutrition among lactating women in developing country

- Education status and family size are highly associated with undernutrition among pregnant women.

\section{What this study adds}

- Even if the magnitude of undernutrition Known in other part of the country but it is not Known the magnitude in Eastern part of country it is also high magnitude depend on WHO classification

- Additional food intake during lactation and mother dietary diversity score is strongly associated with nutritional status of lactating women.

\section{References}

1. UNICEF 2011. United Nations Children's Fund. Programming Guide: Infant and Young Child Feeding. New York . Avaliable at https://www.unicef.org/nutrition/files/Final_IYCF_

2. IYCF 2011. Infant \& Young Child Nutrition Project Literature Review Prepared for the Message and Materials Development Workshop produced through support provided by the United States Agency for International Development, Addis Ababa, Ethiopia 
3. RE, Victora.G, Susan.P Walker, Zulfi qar A Bhutta, Parul Christian, Mercedes de Onis, Majid Ezzati, Sally Grantham-McGregor, Joanne Katz, Reynaldo Martorell and Ricardo Uauy 2013. Maternal and child undernutrition and overweight in low-income and middle-income countries, Lancet 382(98) pp. 427-451.

4. Ransom IE and KL, E. 2013. Nutrition of women and Adolescent girls: Why it matters? Population Reference Bureau.

5. WHO 2014. Comprehensive implementation plan on maternal, infant and young child nutrition. Available at, who.int/nutrition/publications/CIP_document/en

6. S, Rimbawan.R, Dodik.B, Zulaikhah.Z, Nuri.A, Lilis.N, Tonny.S, Laksmi.M and Jacques.B 2016. Nutritional status of lactating women in Bogor district, Indonesia: cross-sectional dietary intake in three economic quintiles and comparison with pre-pregnant women, British Journal of Nutrition 116(1), pp. 67-74.

7. Z, Dang, S. and Yan, H 2010. Nutrient intakes of rural Tibetan mothers: a cross-sectional survey, BMC Public Health,10(801), pp. 1-8.

8. A, Zhang.Y, Li.B, Wang.P, Li.J, Xue.Y, and Gao.H 2014. Prevalence of Anemia and Its Risk Factors Among Lactating Mothers in Myanmar, American Journal of Tropical Medicine and Hygine „90(5), pp. 963-967.

9. Eshetu zerihun , Gudina Egeta,. and Frehiwote mesfine, 2017 Undernutrition and its Associated Factors among Lactating Mothers in Rural Ambo District, West Shewa Zone, Oromia Region, Ethiopia, Advances in Nutrition, Food Science \& Technology.

10. Biru Km , Jima .A and Abeya .S 2017. Prevalence of Chronic Energy Malnutrition and Maternal Health Service Utilizations among Lactating Mothers in Adama District, Oromia Region, Eastern Ethiopia, Journal of Food Processing \& Technology, 8(1), pp.1-5.

11. Mihiretu Alemayehu, Alemayehu Arga and Abele G.Mariam 2015. Factors Associated with Malnutrition among Lactating Women in Subsistence Farming Households from Dedo and SeqaChekorsa Districts, Jimma Zone, 2014, iiste 5 (21), pp. 1-9.

12. Temesgen Dessisa ,Habtamu Fkadu, Desalege Wirtu and Dunkana Kenie Nutritional Status and Associated Factors among Lactating Mothers in Nekemte Referral Hospital and Health Centers, Ethiopia, Food Science and Quality Management 35(24), pp.1-11.

13. J, Melmaruvathur.S, Kancheepuram and Tamilnadu. 2013. Nutritional Status among Lactating Women and predictors for infant weight gain in Rural Area of Wardha, India ,journal of maternal and child health, 15 (3), pp. 1 -8.

14. UNICEF 2009. Tracking progress on child and maternal nutrition a survival and development priority:Avaliableat, https://www.unicef.org/.../Tracking_Progress_on_Child_and_Maternal_

15. Fikrewold H. Bitew and Daniel Telake 2010. Undernutrition among Women in Ethiopia: Rural-Urban Disparity, Calverton, Maryland, USA,ICF Macro, pp. 1-31

16. FMoH 2008-2013. Program implementation manual of national nutrition program NNP, A.A Available at; $\underline{\text { moh.gov.et .documentp/.pdf }}$ 
17. Rahman, S, Mondal.N, Islam.R, Ahmed.K, Karim, R. and Alam.S 2015. Under Weightiness among Ever-married Non-pregnant Women in Bangladesh: A Population Based Study, Universal Journal of Food and Nutrition Science, 3(2), pp. 29-36.

18. N, Balakrishna.N, Arlappa.A, Laxmaiah.S and Brahmam.G 2010. Diet and nutritional status of women in india, J Hum Ecol 29(3), pp. 165-170.

19. B, Jamuna.T, Pukar.T, Matina.S, Bishnu.P and Megha.R 2016. Dietary intake patterns and nutritional status of women of reproductive age in Nepal: findings from a health survey, Archives of Public Health, 74(2), pp. 1-11.

20. S, Borne.D and Guy Plasqui 2014. Body composition, water turnover and physical activity among women in Narok County, Kenya, BMC Public Health 14(12), pp. 1-8.

21. A and Falana.M 2009. The Nutritional Status of Mothers Practicing Breast Feeding In Ibadan, Nigeria, African Journal of Biomedical Research, 12(2) ,pp. 1-7.

22. Sileshi Berihun, Getachew Mullu Kassa and Muluken Teshome 2017. Factors associated with underweight among lactating women in Womberma woreda, Northwest Ethiopia; a crosssectional study, BMC Nutrition, 3(46), pp. 1-7.

23. Negassie Berhe Weldehaweria ,Kebede Haile Misgina, Meresa Gebremedhin Weldu, Yosef Sibhatu Gebregiorgis, 2016 . Dietary diversity and related factors among lactating women visiting public health facilities in Aksum town, Tigray, Northern Ethiopia, BMC Nutrition 2(38)

24. Kiday Hailesslasie, Afework Mulugeta and Meron Girma., 2013. Feeding practices, nutritional status and associated factors of lactating women in Samre Woreda, South Eastern Zone of Tigray, Ethiopia, Nutrition Journal 12(28), pp. 1-11.

25. S , Brijesh P, Singh.O, Singh and Gupta, P. 2015. Variation in body mass index and their determinants among married women in Uttar Pradesh, International Journal of Health,3 (2), pp. 52-55.

26. $P$ 2014. underlying causes of child and maternalmalnutrition in the estate sector of srilanka, Journal of south asian studies, 02(03), pp. 241-255.

27. Seifu Hagos, Torlief Lunde, Damen H.Mariam, Tassew Woldehanna and Bemnet Lindtjørn, 2015.Is the adapted Household Food Insecurity Access Scale (HFIAS) developed internationally to measure food insecurity valid in urban and rural households of Ethiopia?, BMC Nutrition, 1(2),

28. J, Anne .S and Paula.B 2007. Household Food Insecurity Access Scale (HFIAS) for Measurement of Food Access: Indicator Guide VERSION 3 , August 2007. Available at,https://www.fantaproject.org/monitoring.../household-food-insecurity-access-scale-hfi

29. G, Tellier.B. and Claude .M 2010. Guidelines for Measuring Household and Individual Dietary Diversity', pp. 1-60.available at www.fao.org/3/a-i1983e.pdf

30. A, Glauber.L, Oliveira.D and Ornellas.J 2005. Technical error of measurement in anthropometry. Rev Bras Med Esporte, 11(7), pp 86-90

31. NHANES (National Health and Nutrition Examination Survey). 2007. Anthropometry procedures manual https://www.cdc.gov/nchs/data/nhanes/nhanes_07_08/manual_an.pdf 
Figures

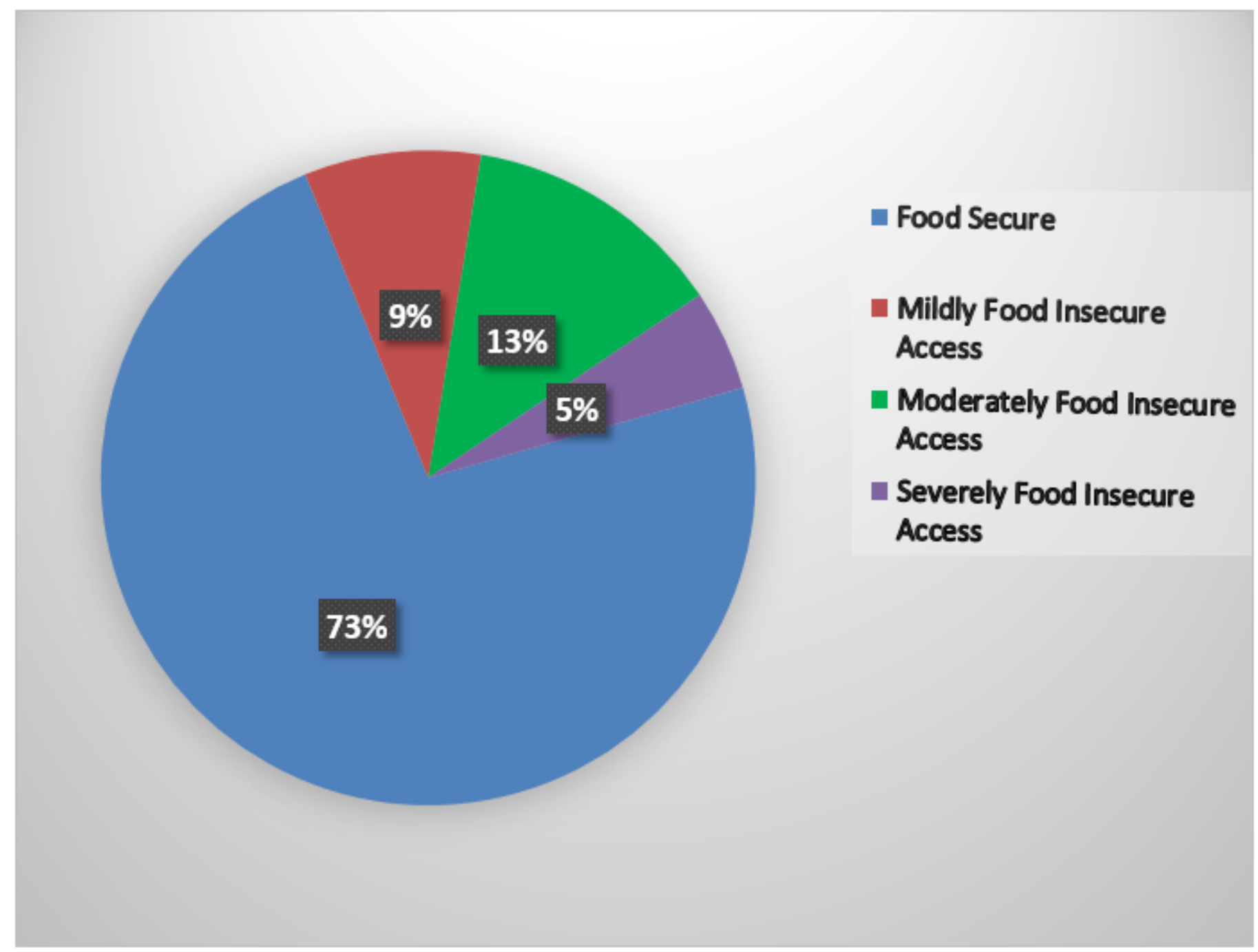

Figure 1

Household food security levels among the study participants in Dire Dawa town, Eastern Ethiopia, $2019 / 20(n=401)$ 
80

70

60

50

40

30

20

10

0

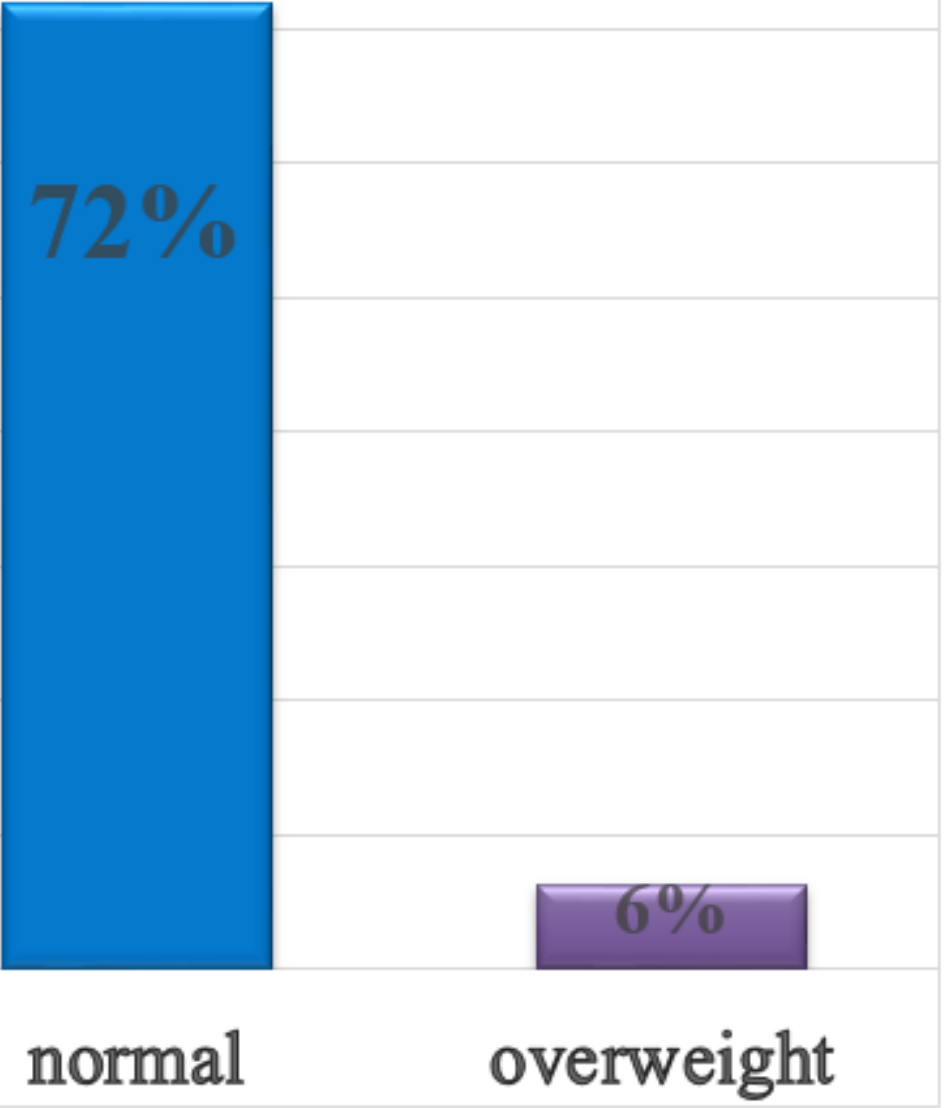

Figure 2

Nutritional status of study participants Using BMI in Dire Dawa town, Eastern Ethiopia, 2019/20 (n=401) 